\title{
CYTOTOXIC SATURATED FATTY ACIDS FROM THE INDONESIAN SEA CUCUMBER Holothuria sp.
}

\section{Asam Lemak Jenuh Sitotoksik dari Teripang Holothuria sp. Asal Indonesia}

\author{
Hedi Indra Januar*, Muhamad Nursid, and Ekowati Chasanah ${ }^{1}$ \\ ${ }^{1}$ Research and Development Center for Marine and Fisheries Product Processing and Biotechnology, \\ Jl. K.S. Tubun Petamburan VI, Jakarta Pusat 10260, Indonesia, *Correspondence Author: idjanuar@gmail.com \\ Article history: \\ Received: 10 January 2014; Revised: 18 April 2014; Accepted: 27 April 2014
}

\begin{abstract}
Sea cucumbers are one of Indonesia's marine organism with the potential to be developed as possible herbal medicines. In a preliminary study of cytotoxic activity of ethanol extracts of 14 Indonesian sea cucumber species, the most active extract came from the Holothuria sp. The current research aimed to identify the major cytotoxic component in the sea cucumber Holothuria $\mathrm{sp}$., that yielded the most active extract. The samples were collected from South Lampung beach. Isolation of the cytotoxic component was done employing liquid flash and preparative reversed phase (C18) chromatography. Cytotoxicity evaluation of fractions collected during the chromatography was conducted using the MCF-7 tumor cell line. Elucidation of the structure of most active isolate was done by NMR (Nuclear Magnetic Resonance) spectroscopy and GC-FID (Gas-Chromatography-Flame lonisation Detector) analysis. The results of these analyses showed the most active compound to be stearic acid; $I C_{50}$ towards MCF-7 cells $10.32 \mathrm{ppm}$.
\end{abstract}

Keywords: Holothuria sp., cytotoxicity, MCF-7, stearic acid

\begin{abstract}
ABSTRAK
Teripang adalah salah satu biota laut Indonesia yang sangat prospektif untuk dikembangkan sebagai obat herbal. Pada studi sitotoksik pendahuluan yang dilakukan terhadap ekstrak etanol dari 14 spesies teripang Indonesia, ekstrak teraktif ditemukan berasal dari jenis Holothuria sp. Oleh karena itu, penelitian ini bertujuan untuk mengetahui komponen sitotoksik mayor dalam teripang Holothuria sp. asal Indonesia. Sampel biota uji diperoleh dari Pantai Lampung Selatan. Proses isolasi senyawa sitotokik dilakukan dengan teknik kromatografi flash dan preparatif fasa terbalik (C18). Uji sitotoksititas dari fraksi-fraksi yang dihasilkan dari proses kromatografi dilakukan terhadap sel lestari tumor MCF-7. Elusidasi struktur yang mempergunakan teknik spektroskopi NMR (Nuclear Magnetic Resonance) dan GC-FID (Gas Chromatography-Flame Ionisation Detector) menemukan bahwa komponen paling aktif pada ekstrak ini adalah asam lemak jenis asam stearat. $I C_{50}$ dari senyawa ini adalah sebesar $10.32 \mathrm{ppm}$ terhadap pertumbuhan sel lestari MCF7 .
\end{abstract}

Kata Kunci: Holothuria sp., sitotoksisitas, MCF-7, asam stearat

\section{Introduction}

Sea cucumbers are well known as one of the marine animals that is commercially important as human food. Extracts of these animals are widely used as ingredients in traditional medicine (Wijesinghe et al., 2013). This bio-potential has been reported in many publications that outline various activities of sea cucumber extracts, including; antioxidant (Liu et al., 2012), antimicrobial (Moguel-Salazar et al., 2013), and anticancer (Silchenko et al., 2012). These extracts are know to contain a broad range of secondary metabolites such as phenolics, triterpene glycosides, saponins, fatty acids, and cytotoxins, any number of which may act as the source of observed biological properties (Bordbar et al., 2011).

In spite of Indonesia being one of the major sources of sea cucumbers in the world, there are few publications concerning identification and evaluation of their reportedly biological active compounds. There are reports of biological activity in Indonesian sea cucumbers, such as antifungal (Pranoto et al., 2012), antibacterial (Nimah et al., 2012), and anticancer 
(Albuntana et al., 2011; Inayah et al., 2012; Mangindaan \& Fitje Losung, 2013), but investigations that discuss the active metabolites are few. In a previous preliminary study of cytotoxic activity ethanol extracts of 14 Indonesian sea cucumber species, the most active extract came from a Holothuria sp., sample (Chasanah et al., 2013). In this paper we report research results that aimed to identify the major cytotoxic compound(s) from the Indonesian sea cucumber Holothuria sp. The information gleaned from this study may serve as baseline data for optimization of herbal medicine development from Indonesian sea cucumbers.

\section{Materials and Methods}

\subsection{Animal Materials}

Holothuria sp., specimen was collected from South Lampung Bay, Indonesia. The sea cucumber taxonomy was undertaken by Siti Nursiyamah, Faculty of Fisheries and marine Science, Bogor Agricultura University. The animals were cleaned to remove the body fluid. Fresh samples were rinsed in fresh water and cut into pieces.

\subsection{Extraction and Fractination}

From collected samples $200 \mathrm{~g}$ of body wall was immersed in $100 \mathrm{~mL}$ ethanol (EtOH) and maintained at $4^{\circ} \mathrm{C}$ in cool box with ice for transportation to the laboratory. At the laboratory, tissue was extracted twice with $100 \mathrm{~mL}$ EtOH and the solvent removed under reduced pressure. Prior to and HPLC (High Performance Liquid Chromatography) separation all samples, extract $(0.55 \mathrm{~g})$, were filtered employing reversed flash chromatography using $\mathrm{C} 18$ silica (Phenomenex) with methanol $(\mathrm{MeOH})$ and dichloromethane (DCM) (1:1) as mobile phase. The resultant filtered dry extract was diluted in $10 \mathrm{~mL}$ of $\mathrm{EtOH}$ and injected repeatedly $(2.5 \mathrm{~mL} /$ injection $)$ into a preparative Simadzu HPLC system. The system employed a $15 \mathrm{~mL} / \mathrm{min}$ gradient elution from $10 \%$ acetonitrile : water to $100 \%$ acetonitrile with a column $250 \times 20$ mm RP Shimadzu C18 over 30 minutes. Fractions, 60 in all, were collected every 30 seconds. A $1 \mathrm{~mL}$ aliquot of each fraction was dried and tested for its cytotoxic properties. The cytotoxic analysis for all fractions was conducted at the Primate Research Center, Bogor Agricultural University, Indonesia, using 3-(4,5-dimethylthiazol-2-yl)-2,5-diphenyltetrazolinon bromide (MTT) assay with MCF-7 cancer cells.

\subsection{Elucidation of Active Compounds}

Elucidation analysis was done with only the most active fraction as determined by the cytotoxicity assay.
Elucidation was undertaken through interpretation of NMR spectorscopic and qualitative GC-FID data.

The dry active fraction was redissolved in $0.65 \mathrm{~mL}$ deuterated chloroform (Merck 99.9\%). NMR spectra were recorded on a Jeol $400 \mathrm{MHz}$ NMR spectrometer, with spectra referenced to the residual ${ }^{1} \mathrm{H}(\mathrm{d} 7.26)$ and ${ }^{13} \mathrm{C}(77.0 \mathrm{ppm})$ resonances in the deuterated solvents.

Further confirmation of the active compound's identity was undertaken by comparison of its GC-FID to reference standards (fatty acids) employing an Agilent 7700 GC-FID. Esterification of fatty acids in the active fraction was achieved by the direct $\mathrm{BF}_{3}$ esterification method of O'Fallon et al. (2007). For this $50 \mathrm{uL}$ of the fraction was added to $2 \mathrm{~mL}$ of $\mathrm{BF}_{3}$ in $\mathrm{MeOH}(14 \%, v / v)$ and heated, at $55^{\circ} \mathrm{C}$ for 1.5 hours. After cooling, the solution was added to $2 \mathrm{~mL}$ of HPLC grade $\mathrm{H}_{2} \mathrm{O}$ and $3 \mathrm{~mL}$ of hexane. The esterificated FAME was in upper layer of $3 \mathrm{~mL}$ hexane. The hexane fraction was concentrated under nitrogen concentrator to $100 \mathrm{uL}$ prior to analysis by GC-FID. The GC system employed a HP- 5 capillary column $(30 \mathrm{~m} \times 0.25 \mathrm{~mm})$ Initial oven temperature was $140^{\circ} \mathrm{C}$, held for $5 \mathrm{~min}$, subsequently increased to $240^{\circ} \mathrm{C}$ at a rate of $4^{\circ} \mathrm{C} /$ $\mathrm{min}$, and then held for $20 \mathrm{~min}$. Helium was used as carrier gas. Injector and detector temperatures were set at $260^{\circ} \mathrm{C}$ and the injection volume was $2 \mathrm{uL}$ with a 50:1 split. Identification was achieved by comparison of the main peak in the sample with fatty acid standards (Supelco 37 Component FAME mix in methylene chloride, catalog 47885-U).

\section{Results and Discussion}

The ethanol extract of Holothuria sp., showed an activity on a pair with the commercial anticancer drug doxorubicin (CAS: 23214-92-8). At 30 ppm, the commercial drug reduced the growth of HeLa cells by $93.5 \%$, in comparison the extract had an activity as high as $97.9 \%$ (Chasanah et al., 2013). This finding may mean the extract contains promising cytotoxic compounds that could to be developed as herbal medicines. Bioassay analysis of all fractions from the HPLC separation showed activity varied from $1-95.5 \%$ inhibition of MCF-7 cell growth. The most active fraction was 45 which eluted after 22 min with the applied gradient mobile phase and an RP-C18 reversed phase column. With this system it was concluded that the compound was relatively non-polar. Further bioassay analysis of this fraction found the cytotoxic $\mathrm{IC}_{50}$ to be $10.32 \mathrm{ppm}$ towards MCF-7 cells.

The ${ }^{1} \mathrm{H}$ and ${ }^{13} \mathrm{C}$ NMR data (Figure 1) of fraction 45 indicate that the active compound to be a aliphatic compounds. NMR DEPT (Distortionless Enhancement of Polarisation Transfer) and ${ }^{1} \mathrm{H}-\mathrm{NMR}$ integration data 


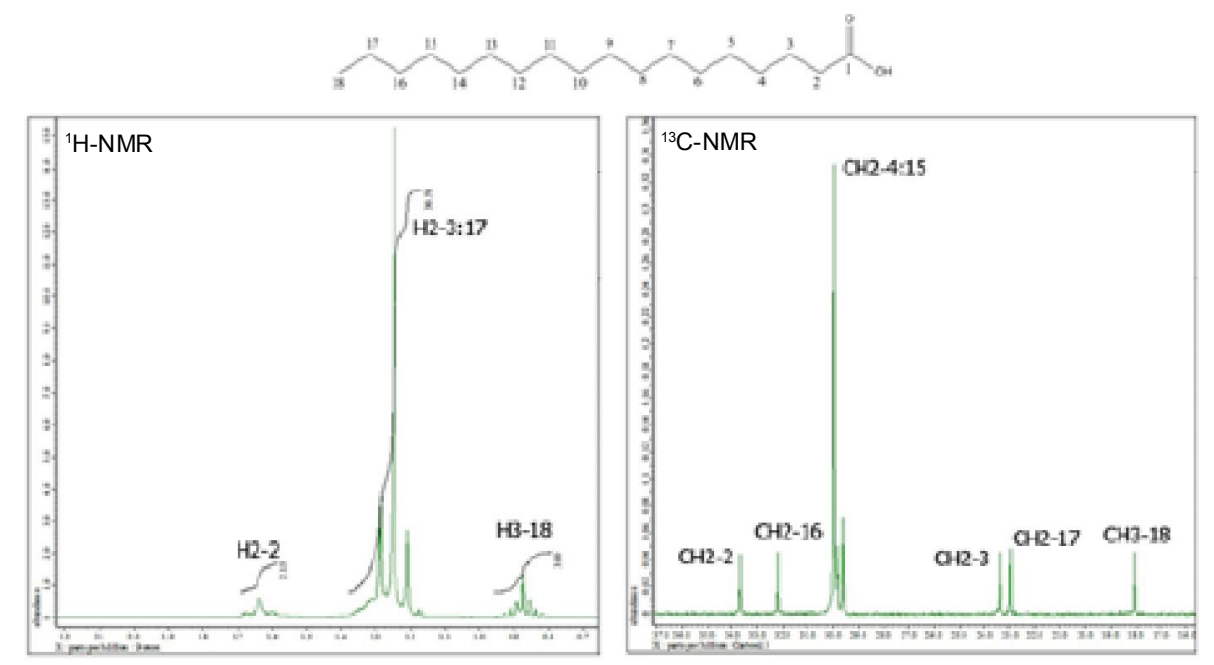

Figure $1 .{ }^{1} \mathrm{H}$ and ${ }^{13} \mathrm{C}$ (Acid carbonyl resonance not shown) NMR spectra of active fraction 45 (Stearic acid).

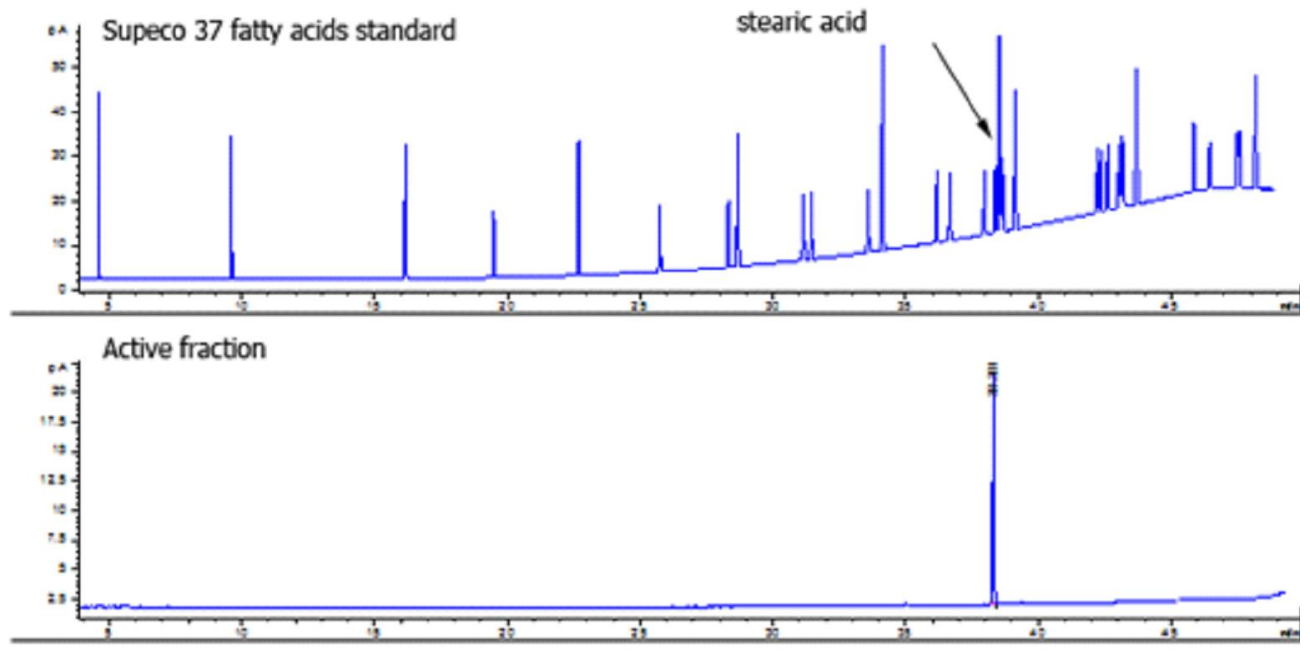

Figure 2. GC-FID chromatogram of fatty acids standards (A) and the active fraction 45 (B) (Stearic acid).

showed the evidence that the compound had $1 \mathrm{CH}_{2}$ at $1.65 \mathrm{ppm}, 1 \mathrm{CH}_{3}$ at $0,88 \mathrm{ppm}$, and approximately 15 $\mathrm{CH}_{2}$ around 1.2-1.4 ppm. Carbonyl group was suggested by the presence of one methyl group at the proton at $1.65 \mathrm{ppm}$. HSQC (Heteronuclear Single Quantum Coherence) analysis showed that the chemical shift in 1H-NMR spectra at 1.2-1.4 ppm (related to the carbons at $30 \mathrm{ppm}$ in 13C-NMR) was an overlaid of $\mathrm{CH}_{2}$ Group. This lead to a suggestion that the compound is an aliphatic and saturated fatty acids. This suggestion was confirmed by GC-FID analysis of fraction 45 (Figure 2). Comparison to the chromatogram of fatty acid standards with that for fraction 45 confirmed that the fraction contain a single compound, stearic acid.

Stearic acid is a SFA (Saturated Fatty Acids). This class of fatty acids is one of the major fatty acid classes within sea cucumbers (Yahyavi et al., 2012). As it has a carbon chain within the range $\mathrm{C} 16-24$, it also considered a LCFA (Long Chain Fatty Acids). This class is well known to have potential as cytotoxic agents, to have anti-proliferative actions, inducers of oxidative stress and as modifiers of intracellular signaling pathways (Fauser et al., 2011). Other research has also reported the activity of stearic acid as being a cytotoxic compound (Brinkmann et al., 2013). The cytotoxic activity in LCFAs is known to be reversed with the length of the carbon chain. The palmitic acid (C16) is more toxic than arachidic acid (C20) (Siegel et al., 1987).

The finding of this type of compound as the most cytotoxic isolate in this sea cucumber species is rare. Usually, triterpene glycosides or sapoins are shown to be the cytotoxic compounds isolated from this 
organism (Mohammadizadeh et al., 2013). This paper is the first report of a common fatty acid to be the most cytotoxic compound in the sea cucumber Holothuria sp. It is probable that other classes of cytotoxic compounds are present in these organisms but towards other cancer cell types. Ridzwan et al. (2014) stated that besides SFA, holothurians are also known to contain PUFA (Polyunsaturated Fatty Acids), that are commonly encountered human essential fatty acids such as EPA (Eicosapentanoic acid) and DHA (Docosahexanoid acid). Polyunsaturated fatty acids, such as DHA, are known to have preventive effects in relation to cancer growth (Gleissman et al., 2010). However, as this research did not find any cytotoxic effects with fractions other than the stearic acid fraction, this may mean that such fatty acids have a different mechanism of action and thus selectivity in prevention of the growth of specific tumor cell lines.

Moreover, as this research reveals that the major cytotoxic compound in the holothurian extract was a SFA there are several things that need to be considered if there is to be any product development. First, besides possessing promising cytotoxic activity, the SFA in question may have a negative impact on human health as it is known that dietary SFAs may contribute to cardiovascular disease (Hooper et al., 2011). Therefore, the development of any products from sea cucumbers as herbal medicines will require very careful control of dosage compared to other nutraceuticals, food supplements, or functional foods, to prevent any adverse effects. Also, it is known that these classes of compounds are susceptible to aerial oxidation (Yi et al., 2013). This means any formulation of a potential product containing SFAs from sea cucumbers has to take this into account (Xu et al., 2013).

\section{Conclusions}

This research identified stearic acid as the most cytotoxic compound in the cytotoxic organic solvent (EtOH) extract of the sea cucumber Holothuria sp., from South Lampung Beach, Indonesia. The cytotoxicity was found to be comparable to that of the anticancer drug doxorubicin. If a herbal product is to be developed from Holothuria sp., there are several things that need to be considered First, a toxicity study needs to determine possible undesirable toxic effects of both the extract and the pure compound. Once toxicity is known and found not to be and issue an appropriate formulation and dose needs to be determined.

\section{Acknowledgement}

Acknownledgement goes to S. Mariya, Primate Research Center, Bogor Agricultural University, Indonesia, for performing the cytotoxic assay. We also thank to Sri Iswani, Indonesian Research and Development Center for Marine and Fisheries Products Processing and Biotechnology, for helping in sample preparation and extraction.

\section{References}

Albuntana, A., Yasman, \& Wardhana,W. (2011) Toxicity test of extracts of the four sea cucumber (Holothuriidae) from East Penjaliran, Seribu Islands, based on Brine Shrimp Lethality Test (BSLT) Indonesian Journal of Tropical Marine Science and Technology, 3(1), 65-72.

Brinkmann, C. R., Brodkorb, A., Thiel, S., \& Kehoe, J. J. (2013) The cytotoxicity of fatty acid/á lactalbumin complexes depends on the amount and type of fatty acid. European Journal of Lipid Science and Technology, 115(6), 591-600.

Bordbar, S., Anwar, F., \& Saari, N. (2011) High-Value Components and Bioactives from Sea Cucumbers for Functional Foods-A Review. Marine Drugs, 9, 1761-1805.

Chasanah, E., Kustiariyah, Nursid, M., Susilowati, R., \& Januar, H.I. (2013) Sea cucumber Development as The Raw Material in Nutraceutical Industry. Research and Development Technical Report. Indonesian Research and Development Center of Marine and Fisheries Products Processing and Biotechnology.

Fauser, J. K., Prisciandaro, L. D., Cummins, A. G., \& Howarth, G. S. (2011) Fatty acids as potential adjunctive colorectal chemotherapeutic agents. Cancer Biology Theraphy, 11(8), 724-731.

Gleissman, H., Johnsen, J. I., \& Kogner, P. (2010) Omega3 fatty acids in cancer, the protectors of good and the killers of evil?. Experimental Cell Research, 316(8), 1365-1373.

Hooper, L., Summerbell, C.D., Thompson, R., Sills, D., Roberts, F.G., Moore, H., \& Davey-Smith, G. (2011) Reduced or modified dietary fat for preventing cardiovascular disease. Cochrane Database of Systematic Reviews 2011, 7, DOI: 10.1002/ 14651858.CD002137.pub2.

Inayah,N., Ningsih, \& Adi T.K. (2012) Toxicity and identification of bioactive compound class in etanol and n-hexana extract from dried Holothuria scabra taken at Kenjeran beach - Surabaya. Alchemy, 2(1), 92-100.

Liu, X., Zhenliang, S., Miansong, Z., Xiumei, M., Xuekui, X., Wenpeng, Y., Feng, X., \& Changheng, L. (2012) Antioxidant and antihyperlipidemic activities of polysaccharides from sea cucumber Apostichopus japonicus." Carbohydrate Polymers, 90(4), 16641670.

Mangindaan, R.E.P \& Losung, F. (2013) Hemolytic activity of sea cucumber Bohadschia graeffei from Malalayang beach North Sulawesi in the variation of temperature and $\mathrm{pH}$. Indonesian Journal of Science, 13(1), 27-32.

Mohammadizadeh, F., Ehsanpor, M., Afkhami, M., Mokhlesi, A., Khazaali, A., \& Montazeri, S. (2013) 
Antibacterial, antifungal and cytotoxic effects of a sea cucumber Holothuria leucospilota, from the north coast of the Persian Gulf. Journal of the Marine Biological Association of the United Kingdom, 93(05), 1401-1405.

Moguel-Salazar, F., Ortiz-Vázquez, E., Rodríguez-Canul, R., \& Olivera-Castillo, L. (2013) Antimicrobial activity of aqueous extracts of sea cucumber (Isostichopus badionotus) from the coast of Yucatan, Mexico. African Journal of Microbiology Research, 7(28), 3621-3626.

Nimah, S.., Ma'ruf . W.F., \& Trianto, A. (2012) Bioactivity analysis of sea cucumber (Holothuria scabra) extract to Pseudomonas aeruginosa and Bacillus cereus. Indonesian Journal of fisheries, 1(1), 1-8.

Pranoto, E.N., Ma'ruf, W.F., \& Pringgenies, D. (2012) Assesment of Holothuria scabra bioactivity to Candida albicans. Indonesian Journal of Fisheries Product Processing and Biotechnology, 1(1), 1-8.

Ridzwan, B. H., Hanita, M. H., Nurzafirah, M., Norshuhadaa, M. S., \& Hanis, Z. F. (2014) Free Fatty Acids Composition in Lipid Extracts of Several Sea Cucumbers Species from Malaysia. International J. of Bioscience, Biochemistry, and Bioinformatics, 4(3): 204-207.

Siegel, I., Yaghoubzadeh, E., Keskey, T. S., \& Gleicher, N. (1987) Cytotoxic effects of free fatty acids on ascites tumor cells. Journal of the National Cancer Institute, 78(2), 271-277.

Silchenko, A. S., Kalinovsky, A. I., Avilov, S. A., Andryjaschenko, P. V., Dmitrenok,P. S., Yurchenko, E.
A., \& Kalinin, V. I. (2012) Structures and cytotoxic properties of cucumariosides $\mathrm{H} 2, \mathrm{H} 3$ and $\mathrm{H} 4$ from the sea cucumber Eupentacta fraudatrix. Natural product research. 26(19), 1765-1774.

O'Fallon, J.R., Busboom, J.R., Nelson M.L., \& Gaskins M.T. (2007) A direct method for fatty acid methyl ester synthesis: Application to wet meat tissues, oils, and feedstuffs. Journal of Animal Science, 85, 15111521.

Wijesinghe, W. A. J. P., Jeon, Y. J., Ramasamy, P., Wahid, M. E. A., \& Vairappan, C. S. (2013) Anticancer activity and mediation of apoptosis in human HL-60 leukaemia cells by edible sea cucumber Holothuria edulis extract. Food Chemistry, 139(1), 326-331.

Xu, J., Zhao, W., Ning, Y., Bashari, M., Wu, F., Chen, H., Yang, N., Jin, Z., Xu, B., Zhang, L., \& Xu, X. (2013) Improved stability and controlled release of ù $3 / u ̀ 6$ polyunsaturated fatty acids by spring dextrin encapsulation. Carbohydrate Polymers, 92(2), 16331640.

Yahyavi, M., Afkhami, M., Javadi, A., Ehsanpour, M., Khazaali, A., \& Khoshnoo, R. (2012). Fatty acid composition in two sea cucumber species, Holothuria scabra and Holothuria leucospilata from Qeshm Island (Persian Gulf). .African Journal of Biotechnology, 11(12), 2668-2668.

Yi, J., Zhu, Z., Dong, W., McClements, D. J., \& Decker, E. A. (2013) Influence of free fatty acids on oxidative stability in water-in-walnut oil emulsions. European Journal of Lipid Science and Technology, 115, 10131020. 